\title{
Exploring Online Learning Experiences during the Covid-19 Pandemic
}

\author{
Khusnul Khotimah ${ }^{1, *}$ \\ ${ }^{1}$ Curriculum and Educational Technology, Universitas Negeri Surabaya, Surabaya, Indonesia \\ ${ }^{*}$ Corresponding author. Email: khusnulkhotimah@unesa.ac.id
}

\begin{abstract}
This article describes the learning experiences of students in online learning during the Covid-19 pandemic. Qualitative observation methods and online interviews were conducted, to obtain information about online learning patterns that are often applied by lecturers; the platform that has been selected, the media used by the lecturers; time-frame, student learning experiences, and student responses to lectures. This study reveals that students tend to choose the application of various online learning patterns and simple platforms. As the first conclusion, in search of meaningful online learning experiences, coordinated online learning between pedagogy, technology, and organizational support can effectively foster appropriate learning experiences. The second conclusion is we need to critically examine the benefits and limitations of the types of asynchronous, synchronous, and hybrid online learning encountered. This will facilitate understanding of future complex assignments and can benefit from student learning experiences.
\end{abstract}

Keywords: Online Learning, Learning Experiences, Online Learning Patterns, Asynchronous, Synchronous, Hybrid Learning.

\section{INTRODUCTION}

Administrators of higher education institutions must fulfill the rights of students to obtain learning services [1]. As the development of communication and information technology is increasingly advanced, the fulfillment of student learning services also requires a touch of technological advancement. One way to improve learning services is that lecturers are required to create innovative learning. This learning will encourage students to be able to study optimally, both in independent learning and in-classroom learning [2].

Along with that, in response to the 2019 coronavirus disease (COVID-19) pandemic that occurred globally, 107 countries have implemented national school closures on March 18, 2020, including Indonesia. This is also a response to the announcement of the World Health Organization (WHO) which declared the 2019 coronavirus disease (COVID-19), which is caused by the coronavirus acute respiratory syndrome, to be a pandemic on 12 March 2020 [3] [4].

The United Nations Educational, Scientific, and Cultural Organization estimates that 107 countries that have implemented national school closures related to COVID-19 affect 862 million children and adolescents, roughly half of the global student population. This situation is rapidly escalating from 29 countries with national school closings the week before. School closures are based on evidence and assumptions from previous influenza outbreaks, reducing social contact between students will interfere with the transmission of the outbreak [5].

The sudden closure of schools resulted in various adjustments. An online learning system is the only option, to replace direct learning. Students and educators from various levels of education from elementary, junior high, and high school to higher education must suddenly have the ability to learn and teach online. All competency 
standards in various disciplines without exception are also taught online [6].

Effective online learning is the result of good collaboration between pedagogy, technology, and organizational support. For an online learning experience, students must learn from the third element, and be active in exploring the experiences online learning provides [4].

Pedagogy, the pedagogy approach needs to be considered in the online learning system to help achieve goals. What must be avoided is a mismatch between the online learning design and the pedagogy used. What often happens is that traditional lecture formats are directly incorporated into online-based instruction without adjustments being made to include activities and assignments [7] [8].

Technology, online technology is implemented to create interactive online environments that result in communications, presentations, simulations, and demonstrations. Technology will look good as long as it facilitates student interaction, is easy to use, and is reliable [9].

Organizational support, for most higher education institutions and universities, technology often appears on the list of achievements of an institution. Overall organizational support for student services, faculty development and training, curriculum development, evaluation, and assessment, and technology often goes beyond the resources of an institution. Therefore, the institution will seek accreditation, partnerships between vendors, and cooperation with other universities to support its achievement [10].

\section{METHOD}

There are two main data to be obtained in this research, namely the online learning platforms and the online learning patterns. Therefore, two data collection methods were used, namely observation and interviews.

Data on the online learning platform was obtained through observation of the platform used by students in lectures during the Covid-19 pandemic. The researchers conducted interviews with 24 students who took online lectures to gain online learning patterns data. The selection of the research subject uses a random sample technique. Interviews were conducted online. The research data collection tool in the form of interview guidelines. The interview data were analyzed by entering answers in the same sub-material group category and adding new sub-materials if needed.

\section{RESULTS AND DISCUSSION}

From the data collected by predetermined methods, and then the data were analyzed, the researchers obtained the information which can be seen in the following table.
Table 1. Online learning patterns

\begin{tabular}{|c|c|c|c|}
\hline & Pattern 1 & Pattern 2 & Pattern 3 \\
\hline Session & Asynchronous & Synchronous & $\begin{array}{l}\text { Asynchronous } \\
\& \text { synchronous }\end{array}$ \\
\hline Platform & $\begin{array}{l}\text { Forum, Edmodo, } \\
\text { Google } \\
\text { Classroom }\end{array}$ & $\begin{array}{l}\text { Chat room, } \\
\text { Zoom meeting, } \\
\text { Google meet, }\end{array}$ & $\begin{array}{l}\text { Moodle, All } \\
\text { platform, }\end{array}$ \\
\hline Media & $\begin{array}{l}\text { PPT's, PDF, } \\
\text { video, audio, } \\
\text { Active links, } \\
\text { TedEd }\end{array}$ & $\begin{array}{l}\text { PPT's, video, } \\
\text { audio }\end{array}$ & All media \\
\hline Time-frame & $\begin{array}{l}2 \text { times per week } \\
\text { maksimum }\end{array}$ & $\begin{array}{l}1 \text { to } 2 \text { times per } \\
\text { week minimum }\end{array}$ & $\begin{array}{l}3 \text { times per } \\
\text { week } \\
\text { maksimum }\end{array}$ \\
\hline $\begin{array}{l}\text { Student } \\
\text { learning } \\
\text { experiences }\end{array}$ & $\begin{array}{l}\text { students make a } \\
\text { project, students } \\
\text { do the exercises, } \\
\text { students do } \\
\text { assignments, } \\
\text { flexible learning, } \\
\text { discovery } \\
\text { learning, } \\
\text { individual } \\
\text { experiment }\end{array}$ & $\begin{array}{l}\text { students listen to } \\
\text { lecturers' } \\
\text { explanations, } \\
\text { students conduct } \\
\text { discussions, ask } \\
\text { questions and } \\
\text { answers }\end{array}$ & $\begin{array}{l}\text { students listen } \\
\text { to lecturers' } \\
\text { explanations, } \\
\text { students } \\
\text { conduct } \\
\text { discussions, } \\
\text { ask questions } \\
\text { and answers, } \\
\text { students do the } \\
\text { exercises, } \\
\text { students do } \\
\text { assignments }\end{array}$ \\
\hline $\begin{array}{l}\text { Student } \\
\text { responses }\end{array}$ & $\begin{array}{l}\text { students are } \\
\text { eager for } \\
\text { interaction }\end{array}$ & $\begin{array}{l}\text { students } \\
\text { complained } \\
\text { about running } \\
\text { out of internet } \\
\text { quota }\end{array}$ & $\begin{array}{l}\text { students gave a } \\
\text { positive } \\
\text { response }\end{array}$ \\
\hline
\end{tabular}

Based on table 1, it shows that there are three online learning patterns, namely asynchronous, synchronous, and a mixture of the two. The following is an explanation of the discussion.

\subsection{Asynchronous Pattern}

Asynchronous online learning patterns, generally facilitated by media such as forums, e-mail, PPT, PDF, video, audio, Active link, TedEd while the well-known platforms are Edmodo and Google Classroom. This Pattern supports learning relationships between students and lecturers, even though they cannot be online at the same time. As such, it is a key component of flexible learning. Many people take online courses because of this asynchronous nature, so they can combine education, work, family, and other commitments [11].

Asynchronous online learning allows students to $\log$ on to the online learning environment at any time and download documents or send messages to lecturers or study colleagues. Students can spend more time helping them, which is generally wiser than synchronous communication [12].

One of the platforms for asynchronous learning is Edmodo. Edmodo is the most popular among the platforms and the most chosen by students. Edmodo was created by Nic Borg and Jeff O'Hara [13], an expert who realizes the need to develop a learning environment to meet global connectedness. Edmodo is a safe platform 
free of advertisements, games, and other distractions that can interfere with student learning [14]. On Edmodo, lecturers can post announcements and assignments for their students. Students can use Edmodo to communicate with their lecturers, so they can ask questions. Students can also collaborate with other classmates on a project for learning.

By using Edmodo, students and lecturers can connect by sharing ideas, problems, and anything useful. A lecturer can assign assignments and rate these assignments directly from the Edmodo page; students can get help from all the classes on Edmodo. Something that cannot be obtained when using direct learning [15]. Students on average give a positive response to Edmodo because according to them learning using Edmodo facilities can increase communication effectiveness in learning and save time [16].

In this pattern, students get a super active learning experience. Student-centered learning and they are required to have self-regulated learning. Methods that can be applied to this pattern are project-based learning, assignments, independent experiments, discovery learning, flexible learning [17].

However, this asynchronous pattern makes students tend to feel frustrated because they feel alone in learning. Their needs for social interaction are becoming more and more increasing.

\subsection{Synchronous Pattern}

Synchronous online learning is generally supported by media such as video conferencing and chat, popular platforms include Zoom meeting and Google meet, both of which are widely chosen by students. This pattern has the potential to support online learning in the development of the learning community [18].

Students are more likely to choose this pattern because this pattern is more social. In synchronous learning, students can ask and answer questions in realtime so that they are not frustrated waiting for a response. Synchronous learning can help students feel more attached and own to their learning and less isolated. Feelings of isolation in online learning can be overcome by communicating in real-time and continuously [19]. They thus become aware of themselves as members of the learning community rather than as isolated individuals communicating with computers [20].

The synchronous pattern makes it possible to monitor student reactions to a message, making recipients feel more committed and motivated to learn. However, the interviews revealed that many students felt that synchronous communication was "more like talking" than asynchronous communication. It seems more acceptable to exchange social support and discuss less "complex" issues. Students feel more stimulated and psychologically motivated because this type of communication is more similar to face-to-face communication [21].

In this pattern, students get active and passive learning experiences, depending on what method the teacher uses. The methods that can be applied to this pattern are discussion, question-and-answer, presentations, and lectures.

However, with the condition of the internet infrastructure in this developing country, the cost to go online is likely expensive. So in this pattern, there will often be complaints from students who run out of internet quota, even though they wish to attend lectures.

\subsection{Hybrid Pattern}

When students learn asynchronously, recipients have more time to understand the message, because the sender does not expect an immediate response. Thus, synchronous patterns increase arousal and motivation, whereas asynchronous patterns increase the ability to process information [22].

The third pattern is a combination of asynchronous and synchronous patterns or we call it a hybrid pattern. To describe how to combine these two patterns we can see in the following table.

Table 2. Asynchronous vs. Synchronous online learning

\begin{tabular}{|c|c|c|}
\hline & $\begin{array}{c}\text { Asynchronous online } \\
\text { Learning }\end{array}$ & $\begin{array}{c}\text { Synchronous online } \\
\text { Learning }\end{array}$ \\
\hline When & $\begin{array}{l}\text { Reflecting on complex } \\
\text { issues } \\
\text { When synchronous } \\
\text { meetings cannot be } \\
\text { scheduled because of } \\
\text { work, family, and } \\
\text { other commitments }\end{array}$ & $\begin{array}{l}\text { Discussing less complex } \\
\text { issues } \\
\text { Getting acquainted } \\
\text { Planning tasks }\end{array}$ \\
\hline Why & $\begin{array}{l}\text { Students have more } \\
\text { time to reflect because } \\
\text { the sender does not } \\
\text { expect an immediate } \\
\text { answer. }\end{array}$ & $\begin{array}{l}\text { Students become more } \\
\text { committed and } \\
\text { motivated because a } \\
\text { quick response is } \\
\text { expected. }\end{array}$ \\
\hline How & $\begin{array}{l}\text { Use asynchronous } \\
\text { means such as a } \\
\text { forum, e-mail, } \\
\text { discussion boards, and } \\
\text { blogs. }\end{array}$ & $\begin{array}{l}\text { Use synchronous means } \\
\text { such as } \\
\text { videoconferencing, } \\
\text { instant messaging and } \\
\text { chat, and complement } \\
\text { with face-to-face } \\
\text { meetings. }\end{array}$ \\
\hline Examples & $\begin{array}{l}\text { Students expected to } \\
\text { reflect individually on } \\
\text { course topics may be } \\
\text { asked to maintain a } \\
\text { blog, etc. } \\
\text { Students expected to } \\
\text { share reflections } \\
\text { regarding course } \\
\text { topics and critically } \\
\text { assess their peers' } \\
\text { ideas may be asked to } \\
\text { participate in online } \\
\text { discussions on a } \\
\text { discussion board. }\end{array}$ & $\begin{array}{l}\text { Students expected to } \\
\text { work in groups may be } \\
\text { advised to use instant } \\
\text { messaging as support for } \\
\text { getting to know each } \\
\text { other, exchanging ideas, } \\
\text { and planning tasks. } \\
\text { A teacher who wants to } \\
\text { present concepts from } \\
\text { the literature in a } \\
\text { simplified way might } \\
\text { give an online lecture by } \\
\text { videoconferencing. }\end{array}$ \\
\hline
\end{tabular}


Table 2 shows how to integrate asynchronous and synchronous patterns in online learning. This pattern is chosen by many students because the deficiencies in both patterns can be overcome. In table II, it can be seen when, why, how, and examples of activities that can be done by students in a hybrid pattern.

\section{CONCLUSION}

In search of meaningful online learning experiences, coordinated online learning can effectively foster appropriate learning experiences. As key players in online learning, students are primarily explored and experienced learning experiences. Students must be actively involved in the learning process and change to provide feedback. This will enhance their online learning experience.

An important challenge in this discussion is that we need to critically examine the benefits and limitations of the types of asynchronous, synchronous, and hybrid online learning encountered. This will facilitate understanding of future complex assignments and can benefit from student learning experiences.

\section{ACKNOWLEDGMENTS}

The authors would like to thank the State University of Surabaya Institution for providing support for this research and for the ICEI Committee which has provided the opportunity to publish this study.

\section{REFERENCES}

[1] P. R. Indonesia, "Undang-undang Republik Indonesia nomor 20 tahun 2003 tentang sistem pendidikan nasional," Jakarta Pemerintah Republik Indones., 2003.

[2] J. Orozco-Messana, J. M. Martínez-Rubio, and A. M. Gonzálvez-Pons, "Sustainable Higher Education Development through Technology Enhanced Learning," Sustainability, vol. 12, no. 9, p. 3600, 2020 .

[3] W. H. Organization, "Coronavirus disease 2019 (COVID-19): situation report, 72,” 2020.

[4] S. A. Ali, M. Baloch, N. Ahmed, A. A. Ali, and A. Iqbal, "The outbreak of Coronavirus Disease 2019 (COVID-19) - An emerging global health threat," $J$. Infect. Public Health, 2020.

[5] R. M. Viner et al., "School closure and management practices during coronavirus outbreaks including COVID-19: a rapid systematic review," Lancet Child Adolesc. Heal., 2020.

[6] S. Esposito and N. Principi, "School closure during the coronavirus disease 2019 (COVID-19) pandemic: an effective intervention at the global level?," JAMA Pediatr., 2020.

[7] S. Hrastinski, "What do we mean by blended learning?," TechTrends, vol. 63, no. 5, pp. 564-569, 2019.

[8] N. Lorenzo and R. Gallon, "Smart pedagogy for smart learning," in Didactics of smart pedagogy, Springer, 2019, pp. 41-69.

[9] L. Kyei-Blankson, E. Ntuli, and H. Donnelly, "Establishing the importance of interaction and presence to student learning in online environments," J. Interact. Learn. Res., vol. 30, no. 4, pp. 539-560, 2019.

[10] M. J. O’Hara and D. A. Peak, “A Quandary for Information Technology: Who Controls the Content of Distance Education?," J. Inf. Syst. Educ., vol. 11, no. 1, p. 5, 2020 .

[11] I. Galikyan and W. Admiraal, "Students' engagement in asynchronous online discussion: The relationship between cognitive presence, learner prominence, and academic performance," Internet High. Educ., vol. 43, p. 100692, 2019.

[12] Y. Chen, X. Sun, and Y. Jin, "Communicationefficient federated deep learning with layerwise asynchronous model update and temporally weighted aggregation," IEEE Trans. Neural Networks Learn. Syst., 2019.

[13] N. Borg, J. O'Hara, and C. Hutter, “About Edmodo," Retrieved December, vol. 3, p. 2013, 2008.

[14] B. Gushiken, "Integrating Edmodo into a high school service club: to promote interactive online communication," 2013.

[15] B. B. Shams-Abadi, S. D. Ahmadi, and A. G. Mehrdad, "The effect of Edmodo on EFL learners' writing performance," Int. J. Educ. Investig., vol. 2, no. 2, pp. 88-97, 2015.

[16] K. M. Al-Said, “Students' Perceptions of Edmodo and Mobile Learning and Their Real Barriers towards Them.," Turkish Online J. Educ. Technol., vol. 14, no. 2, pp. 167-180, 2015.

[17] D. Wu, M. Bieber, and S. R. Hiltz, "Engaging students with constructivist participatory examinations in asynchronous learning networks," J. Inf. Syst. Educ., vol. 19, no. 3, p. 9, 2019.

[18] Ü. Çakıroğlu and S. Kılıç, "Understanding community in synchronous online learning: do perceptions match behaviours?," Open Learn. J. Open, Distance e-Learning, vol. 35, no. 2, pp. 105 $121,2020$. 
[19] W. Wang, L. Guo, L. He, and Y. J. Wu, "Effects of social-interactive engagement on the dropout ratio in online learning: insights from MOOC," Behav. Inf. Technol., vol. 38, no. 6, pp. 621-636, 2019.

[20] D. Henriksen, E. Creely, and M. Henderson, "Folk Pedagogies for Teacher Transitions: Approaches to Synchronous Online Learning in the Wake of COVID-19," J. Technol. Teach. Educ., vol. 28, no. 2, pp. 201-209, 2020.

[21] S. Hrastinski, "Asynchronous and synchronous elearning," Educ. Q., vol. 31, no. 4, pp. 51-55, 2008.

[22] M. N. Demaidi, M. Qamhieh, and A. Afeefi, "Applying Blended Learning in Programming Courses," IEEE Access, vol. 7, pp. 156824-156833, 2019. 